\title{
A COVID-19-vírusfertőzés klinikai felismerését szolgáló új információk és a fej-nyaki régióban dolgozó egészségügyi személyzet védekezésének lehetőségei
}

\author{
Antal Márk dr. ${ }^{1}$ - Szabó Réka Magdolna ${ }^{2}$ - Juhász Zoltán dr. ${ }^{2}$ \\ Vereb Tamás $\mathrm{dr}^{3}{ }^{3}$ - Piffkó József $\mathrm{dr}^{3}{ }^{3}$
}

\begin{abstract}
${ }^{1}$ Szegedi Tudományegyetem, Fogorvostudományi Kar, Konzerváló és Esztétikai Fogászati Tanszék, Szeged
${ }^{2}$ Szegedi Tudományegyetem, Általános Orvostudományi Kar, Egészség-gazdaságtani Intézet, Szeged

${ }^{3}$ Szegedi Tudományegyetem, Általános Orvostudományi Kar, Arc-, Állcsont- és Szájsebészeti Klinika, Szeged
\end{abstract}

\begin{abstract}
A feltételezhetően 2019 végén Kínából indult és világjárvánnyá vált koronavírus-betegség (COVID-19) az egészségügyi ellátórendszer minden szegmensét érinti világszerte, így hazánkban is. Mivel az egészségügyi személyzet számos egészségügyi ellátás során kapcsolatba kerülhet vírusfertőzöttekkel is, járvány idején elengedhetetlenül szükséges, hogy a különböző területen dolgozó hazai szakemberek is naprakész információt kapjanak a vírusról és a fertőzésnek a betegellátást befolyásoló aspektusairól, a javasolt intézkedésekről. A jelen közlemény egy irodalmi összefoglaló, melyben a szerzők a jelenleg elérhető, idevágó hivatkozásokat dolgozták fel, szem előtt tartva a klinikumi ellátás járványügyi vonatkozásait. A feldolgozott publikációk alapján kijelenthető, hogy az elsődlegesen a fej-nyak régiót érintő beavatkozások során, kiemelten a forgó eszköz használatát is igénylő intervenciók esetét, elengedhetetlenül szükséges a beavatkozáskor a helyiségben tartózkodó összes munkatárs teljes védelme, egyszer használatos teljes öltözékkel, szemüveggel és speciális maszkokkal. Ezen felszerelések cseréje és a rendelő tisztítása minden beavatkozás után meg kell, hogy történjen, és erre a teljes ellátóteamet oktatással előre fel kell készíteni. Annak érdekében, hogy megelőzhetők legyenek a kezelések alatti keresztfertőzések és a szakemberek fertőzései, elengedhetetlen a munkaegészségügyi és infekciókontroll-intézkedések szigorú betartása.
\end{abstract}

Orv Hetil. 2020; 161(17): 660-666.

Kulcsszavak: koronavírus, COVID-19, SARS-CoV-2, fogászat, szájsebészet, fej-nyak régió

Essential new information for the clinical recognition of COVID-19 infection and the prevention possibilities of healthcare personnel working in the head and neck region

The coronavirus (COVID-19) pandemic probably started in China in 2019 and is influencing the whole healthcare system worldwide. As several healthcare interventions are essential even during pandemics, it is necessary for professionals working in such fields to get up-to-date information about the virus and its aspects that can influence patient care and suggested actions. The current article is a literature review, in which the authors elaborated the recently available scientific articles with their relevancy for clinical interventions as primary factor. The processed articles emphasize that during interventions in the head and neck region, especially when using rotating instruments, it is of utmost importance for all personnel being present at the time of intervention to wear full protection, including disposable medical uniforms, glasses and special masks. These single-use items have to be changed after each intervention and the whole team has to be educated for this process in advance. In order to avoid cross-contamination and infection of personnel during intervention, it is essential to keep all work-safety and infection-control precautions extremely strictly.

Keywords: coronavirus, COVID-19, SARS-CoV-2, dentistry, oral surgery, head and neck region

Antal M, Szabó RM, Juhász Z, Vereb T, Piffkó J. [Essential new information for the clinical recognition of COVID-19 infection and the prevention possibilities of healthcare personnel working in the head and neck region]. Orv Hetil. 2020; 161(17): 660-666.

(Beérkezett: 2020. március 26.; elfogadva: 2020. március 30.) 


\section{Rövidítések}

ARDS = (acute respiratory distress syndrome) akut légzési distressz szindróma; ART (atraumatic restorative treatment) atraumatikus helyreállító kezelés; COVID-19 = (coronavirus disease 2019) koronavírus-betegség 2019; CT = (computed tomography) számítógépes tomográfia; EMMI = Emberi Erőforrások Minisztériuma; FFP = (filtering facepiece) részecskeszűrő félálarc; MERS = (Middle East respiratory syndrome $)$ közel-keleti légzési szindróma; MERS-CoV = (Middle East respiratory syndrome-related coronavirus) MERS-koronavírus; NNK = Nemzeti Népegészségügyi Központ; SARS = (severe acute respiratory syndrome) heveny akut légzőszervi szindróma; SARS-CoV = (severe acute respiratory syndrome coronavirus) heveny akut légzési szindrómát okozó koronavírus; $\mathrm{WHO}=$ (World Health Organization) Egészségügyi Világszervezet

A koronavírusok lipidburokkal rendelkező, egyszálú RNS-vírusok [1]. A 2019 végén Kínában, Wuhan városában jelentkező, kezdetben ismeretlen eredetü tüdőgyulladás [2] kórokozója a jelenleg világjárványt (COVID-19) okozó vírus, mely elsődlegesen az emberi légzőrendszert támadja meg [3]. Az emberról emberre terjedést egyértelmúen bizonyították [4]; egyes közlemények már a teljesen tünetmentes hordozók által átadott fertőzésekről is beszámoltak, akár enyhe tüdőelváltozásokkal [5], de egyes esetekben kimutatható elváltozás nélkül is [6].

$\mathrm{Az}$ eddigi közlések alapján a vírus terjedése minden törekvés ellenére világméretü [7], így - ahogyan más országokban is - a közeljövőben a hazai betegellátás minden szegmensét érinti majd. Egyes ellátások - mint a fogászat, a szájsebészet, a fül-orr-gégészet - sajátosságait figyelembe véve a beavatkozások alatti keresztfertőzések és a kezelő egészségügyi személyzet fertőzése igen magas rizikójú lehet [8]. Mivel a fogászati eredetú fájdalom a legintenzívebb fájdalmak egyike, továbbá egyes szájüregi kórképek komolyabb tályogos vagy akár phlegmonosus elváltozásokat okozhatnak, a sürgősségi fogászati és szájsebészeti ellátás folyamatos kell, hogy legyen járvány idején is. Ezen túlmenően egyes, enyhébb lefolyású koronavírus-fertőzésekkel rendelkező páciensek fül-orrgégészeti szakrendeléseken és háziorvosi rendeléseken is jelentkezhetnek. A jelen tanulmányunk célja áttekinteni a nemzetközi szakirodalomban elérhető, idevágó közleményeket és ajánlásokat, előtérbe helyezve a megbízható forrásból származó tényeket és információkat, kiemelt figyelmet szentelve a koronavírus-fertőzés megelőzésének a fej-nyak régiót érintő szakmai ellátások során.

\section{Módszer}

2020. március 15-20. között a PubMed és ScienceDirect oldalakon részletes keresést végeztünk a „coronavirus” keresőszót, illetve a „covid 19” szavakat használva. Ezenfelül részletes Google Scholar keresést is alkalmaztunk a coronavirus + scientific, coronavirus + guideline, coronavirus + ENT, coronavirus + maxillofacial, coronavirus + ophthalmology és coronavirus + WHO, illetve a coronavirus + dental kombinációkat használva. Az eredményeket minden esetben a 2019. december 1. utáni publikációkra korlátoztuk, illetve igyekeztünk kiszűrni minden médiagenerált, nem hivatalos szakmai közleményt és állásfoglalást. A PubMed- és ScienceDirect-találatokat relevancia szerint szúkítettük, elsődlegesen a terjedés, a fizikai kontaktus és a fej-nyak régió szem előtt tartásával, míg a Google-találatok közül minden esetben csak az első 100 találatot tekintettük át. Ezeken túlmenően a Magyarországon jelenleg elérhető, az NNK és az Egészségügyi Szakmai Kollégium által közzétett, a fertőzésnek leginkább kitett társszakmákat érintő (arc-, állcsont- és szájsebészet, fül-orr-gégészet, szemészet, idegsebészet) ajánlásokat is áttekintettük, továbbá a feldolgozott közlemények során felmerült további, virológiailag és fogászatilag releváns irodalmat is felhasználtuk.

\section{Eredmények}

Az elvégzett online keresések a „coronavirus” keresőszóra a PubMed-en 1195 találatot, a ScienceDirect-en 919 találatot hoztak, míg a „covid 19”-es kombinációra 1179 PubMed- és 396 ScienceDirect-találatot kaptunk. A Google-keresésekre kapott, 584000 feletti találatból a korábban leírtak alapján minden esetben csak az első 100 találat feldolgozása történt meg. Ezek alapján a jelen összefoglalóban összesen 32 szakirodalmi hivatkozás és 13 egyéb dokumentum feldolgozása történt meg.

\section{Hivatalos nómenklatúra és eredet}

A vírus jelenleg hivatalosan elfogadott nemzetközi elnevezése SARS-CoV-2, a betegség nemzetközileg elterjedt megnevezése pedig COVID-19 [9, 10]. A jelen kórokozó a koronavírusok családjába tartozik, azok emberi megbetegedést okozó csoportjának 11. tagja [11]. Hasonló, állati eredetû etiológiával rendelkező vírusokat leírtak 2002-ben (SARS-CoV) és 2012-ben (MERSCoV) is [12]. A COVID-19 kórokozóját elsőként 2019 végén, Kínában, Wuhan városában, Hubei tartományban dokumentálták, akkor még ismeretlen eredetú vírusként [13]. A legelső leírások a megbetegedéseket egy hal- és állatpiachoz kötötték; a későbbi vizsgálatok a kórokozót genetikailag 88-96\%-ban hasonlónak találták egy, a denevérekben is megtalálható koronavírus-alfajhoz, így a tudomány jelenlegi állása szerint onnan mutálódhatott és terjedt át az emberre $[11,14]$.

\section{A koronavirus terjedése}

A COVID-19 a terjedés szempontjából elsődlegesen emberről emberre terjed; a terjedés sebessége a WHO jelenlegi számításai alapján 1,4-2,5 közötti, vagyis egyet- 
len fertőzött személy átlagosan ennyi további embert fertőz meg [15]. Más vírusfajokhoz hasonlóan az elsődleges fertőzőforrás a beteg testváladékai, kiemelten a nyál, az orrváladék és a köpet [16]. Leírtak kimutatható fertőzést székletben [17] és könnyben, illetve szemváladékban is [18], továbbá nosocomialis fertőzés is gyakran előfordulhat [5]. Most már bizonyított, hogy a fertőzés a levegóben megmaradó és terjedő váladékcseppek - vagyis akár a köhögés, beszéd vagy tüsszentés útján a levegóbe jutott részecskék - révén is továbbadható [12]. Ez a terjedési út kiemelten olyan egészségügyi beavatkozások kapcsán lehet jelentős, amelyeknél a levegőbe történő szóródás vagy aeroszolképződés magas, például a még spontán légző páciensek intubálása során [19]. Mindezeken túlmenően több közlemény felhívja a figyelmet arra, hogy a legtöbb fogászati beavatkozásnál az aeroszolképződés igen magas, így a páciens még akkor is fokozott kockázatot jelenthet, ha nem köhög vagy tüsszent, azonban forgó eszközzel vagy ultrahangos depurátorral dolgoznak a szájában [8]. A jelenleg elérhető kutatások alapján a COVID-19 vírusa aeroszol formájában akár 3 órán át fertőzőképes lehet, rézfelületeken 4 óráig, papíron, kartonlemezeken 24 óráig, múanyagon és rozsdamentes acélon pedig 2-3 napig is megmaradhat [20].

\section{Tünetmentes terjedés}

Leírtak olyan láztalan pácienst, akinek a vírusra jellemző semmiféle tünete nem volt, nem mutatott semmilyen légúti vagy gastrointestinalis tünetet, a környezetében azonban bizonyítottan legalább 5 családtagot fertőzött meg [6]. A vírus lappangási ideje átlagban 5-6 nap, de 14 napig terjedhet [21]; illetve találtunk olyan publikációt, mely akár 24 napos lappangási időszakot is lehetségesnek tart [22]. A jelen tudásunk szerint a vírus már a lappangási időszak alatt is fertőzhet, sőt egyes közlemények a már gyógyultnak minősített személyeknél is felvetették a vírus ürítését és ezáltal a fertőzés veszélyét. Ezek alapján egy teljesen tünetmentes beteg is lehet vírushordozó, és okozhat további fertőzéseket [6].

\section{A koronavirus okozta megbetegedés föbb tünetei}

A leggyakrabban jelentkező tünet a láz $(92,8 \%)$, a köhögés $(69,8 \%)$, a légzési zavarok $(34,5 \%)$, az izomfájdalom $(27,7 \%)$, a fejájás $(7,2 \%)$ és a hasmenés $(6,1 \%)$ [23]. Orrfolyás csak az esetek 4\%-ában dokumentált, garatgyulladás $5,1 \%$-ban [23], torokfájdalom 17,4\%-ban fordul elő [24]. Ezen túlmenően, a Brit Rhinologiai Társaság elnöke körlevélben hívta fel a figyelmet a postviralis anosmia jelenségére, mely a koronavírus-infekciókkal kapcsolatban 30-60\%-ban fordulhat elő [25]. A legtöbb beteg esetében normális a fehérvérsejtszám, de volt olyan publikáció, amely 25\%-ban leukopeniáról számolt be [22]. Az intenzív ellátást igénylő páciensek életkorát szignifikánsan magasabbnak találták [24], ugyanakkor volt olyan szerző, aki nem talált ilyen összefüggést [22]. Az egyik legsúlyosabb szövődmény a légzési nehézséget és sokszor halált okozó (gyakran kétoldali) tüdőgyulladás, mely általában CT-felvételeken ad jellegzetes képet. Gyakori az ezzel összefüggésbe hozható akut légúti distressz szindróma (ARDS) és az akut szívelégtelenség, melyek halálhoz vezethetnek [22].

\section{Az egészségügyi szakemberekre vonatkozó speciális rizikótényezốk és javaslatok}

A COVID-19-fertőzés egyik jellemzőjeként leírták, hogy egy adott régióban vagy országban az esetek akár közel 4\%-ában $(3,84 \%)$ az egészségügyi dolgozók is megbetegednek [26]. Már a COVID-19 megjelenése előtt is ismert volt, hogy a fogászati beavatkozások aeroszolképződéssel és a levegőben terjedő kisebb részecskehalmaz-képződésekkel járnak, melyek vírusokat is tartalmazhatnak [27]. Ennek megfelelően a fogászati beavatkozások a jelen vírus esetében is az egyik legkritikusabb terjedési utat jelenthetik, hiszen ezek során szinte kivédhetetlen az aeroszolképződés, miközben folyamatosan nyállal, vérrel vagy egyéb testnedvekkel kerül érintkezésbe az ellátást végző szakember [28]. A nemzetközi társaságok által kiadott állásfoglalások szerint hasonló veszélynek vannak kitéve a fej-nyak régióhoz kapcsolódó társszakmák szakemberei, akik mindennapi diagnosztikai/intervenciós tevékenységüket forgó eszközökkel, ultrahangos eszközökkel vagy endoszkóp alkalmazásával végzik (arc-, állcsontsebészet, fül-orr-gégészet, szemészet, idegsebészet) [29-32]. Mindezek szem előtt tartásával egyértelmű, hogy fokozott szintű járványügyi helyzetben az infekciókontroll szempontjait és az erőforrásokkal történő optimális gazdálkodást egyaránt figyelembe véve, az egészségügyi ellátásban szigorúan csak sürgősségi jellegű beavatkozások elvégzése indokolt. Erre vonatkozólag Magyarországon hivatalos rendelet van érvényben, melyet egy későbbi alfejezetben taglalunk részletesen.

\section{A fogászati beavatkozásokkal kapcsolatos sajátosságok}

Bizonyos fogászati beavatkozások esetén (például elkerülhetetlen trepanáció) a turbina okozta sprayképződés miatt még a fúrás megkezdése előtt, közvetlenül az érzéstelenítés után javallt a kofferdamizolálás felhelyezése. A kofferdam használata már önmagában 70\%-kal csökkentheti a kontaminált aeroszol képződését [33]. Az abszolút izolálás használata mellett szükséges az exhaustor folyamatos használata is, a hagyományos nyálszívóval párhuzamosan [34]. Olyan esetekben, amelyekben nem kivitelezhető a kofferdam használata, megfontolandó az aeroszolképződéssel nem járó megoldások alkalmazása, mint például a kémiai caries eliminatio $[35,36]$ (például Carisolv, D-Solv) vagy az ART- (Atraumatic Restorative 
Treatment) technika [37]. Ajánlott, hogy a kezelések végzése minden esetben négykezes technikával történjen, vagyis alapvetően két fogászati asszisztens együttes jelenléte szükséges a kezelések elvégzéséhez [8, 38]. Kizárólag így biztosítható, hogy kezelés alatt ne kontaminálódjon se a rendelő bútorzata, se a fiókok vagy az esetlegesen nem sterilizálható eszközök.

\section{A fogászati egységkészülék és környezete}

Mind az egységkészülék, mind a rendelő berendezései lehetséges fertőzésforrásként szerepelhetnek. Korábban már tárgyaltuk, hogy a COVID-19 vírusa milyen felületeken mennyi ideig maradhat életképes. Járványidőszakban javallt a rendelő teljes fertőtlenítése minden páciens után; a felületek fertőtlenítésére alkalmas lehet 62-71\%os etanoltartalmú fertőtlenítőszer, $0,5 \%$-os hidrogénperoxid vagy $0,1 \%$-os nátrium-hipoklorit minimálisan 1 perces hatóidővel. Más fertőtlenítők, mint a $0,005-$ 0,2\%-os benzalkónium-klorid vagy a $0,02 \%$-os klórhexidin-diglükonát, kevésbé bizonyultak hatékonynak [39]. Egyes tanulmányok azt javasolják, hogy a felületeket, a padlót és érintettség esetén a falat $1000 \mathrm{mg} / \mathrm{l}$ klórtartalmú fertőtlenítővel tisztítsuk, legalább 30 perces hatóidővel, napi háromszori ismétléssel, illetve ha felmerül a fertőzöttség gyanúja, akkor azonnal a kérdéses páciens után [40].

\section{A fogászati team védelme}

A betegellátás tekintetében az ajánlások két szintet különböztetnek meg. A beteg kezelésében közvetlenül nem részt vevő, ám azzal kapcsolatban egy légtérbe kerülő munkatársak (recepciós, előszûrést, lázmérést végző egészségügyi személyzet) sebészi maszkot, egyszer használatos sapkát és egészségügyi munkaruhát kell, hogy viseljenek. Az ellátást végző team közvetlen tagjai számára ezzel szemben már FFP2-es vagy FFP3-as maszk viselése szükséges (aeroszolképződés esetén az FFP3 javasolt), illetve egyszer használatos sapka, egyszer használatos, vízálló, hosszú ujjú köpeny (az alap-munkaruházaton felül), védőszemüveg vagy védőpajzs és lábzsák [8]. Értelemszerúen ezen egyszer használatos védőfelszereléseket a kezelések között cserélni kell, az alsó munkaruházatot pedig múszakonként kell váltani [40]. Több közlemény is hangsúlyozza, hogy a teljes védőfelszerelések felvételére és eltávolítására is ki kell képezni az egészségügyi személyzetet. A védőfelszerelés felvételét megelőzően minden esetben kézfertőtlenítést kell végezni. Az egyéni védőeszközök felvételének sorrendje: 1. védőköpeny (+ védősapka), 2. FFP2/FFP3 maszk, 3 . védőszemüveg/védőpajzs, 4. gumikesztyű (ráhúzva a védőköpeny ujjára). A védőeszközök levételekor az eljárásrend a következő: 1. a gumikesztyű levétele előtt alkoholos kézfertőtlenítés, 2. a gumikesztyű levétele (ügyelve arra, hogy ne érintsük annak külső felszínét), 3. higiénés kézfertőtlenítés, 4. új gumikesztyü felvétele,
5. köpeny levétele és veszélyeshulladék-tárolóba helyezése, 6. védőszemüveg/védőpajzs levétele (csak oldalt érintve meg az eszközt) és fertőtlenítő oldatba helyezése, 7. FFP2/FFP3 maszk levétele (csak a zsinór érinthetô, oldalt a fülek mellett benyúlva), 8. a gumikesztyú levétele (előtte alkoholos bedörzsölés), 9. a folyamat legvégén ismételten higiénés kézfertőtlenítés [41]. A fogászati kezelések során képződő aeroszol fertőző képessége egyes közlemények szerint csökkenthető a beavatkozás előtti szájöblítéssel, erre elsődlegesen 1\%-os hidrogénperoxid vagy $0,2 \%$-os povidon-jód ajánlott, klórhexidinalapú szájöblítők nem [38].

$\mathrm{Az}$ egészségügyi ellátórendszerben kiemelten fontos feladat a személyzet megfelelő védelme az infekciókontroll és a munkaegészségügy szempontjából is. Figyelembe véve, hogy a koronavírus-fertőzés elsősorban az idősebb korosztályra és/vagy valamilyen alapbetegséggel (szív-ér rendszeri, anyagcsere-, daganatos betegség stb.) rendelkezőkre jelent nagyobb veszélyt a szövődmények kialakulása szempontjából, ezen célcsoportokra fokozottan kell figyelnünk. Megfelelő munkaszervezéssel (például az idősebb kollégák távkonzultációs feladatvállalása) minimalizálni kell az expozíció lehetőségét.

\section{Az ellátás menete és feltételei}

A sürgősségi ellátásra érkező pácienst először meg kell vizsgálni a COVID-19 leggyakoribb tüneteire. Ezek közül javasolt a lázmérés és a páciens alapos kikérdezése egy előre összeállított kérdőív alapján, a következő főbb kérdésekkel: (1) Van-e jelenleg láza, vagy volt-e láza az elmúlt 14 napban? (2) Tapasztalt-e köhögést vagy légzési nehézséget az elmúlt 14 napban? (3) Az elmúlt 14 napban járt-e külföldön? (4) Találkozott-e koronavírussal igazoltan fertőzött beteggel az elmúlt 14 napban? (5) Találkozott-e külföldről érkező személlyel vagy olyannal, akinek az elmúlt 14 napban láza vagy légzési problémái voltak? (6) Volt-e a környezetében legalább két olyan személy az elmúlt 14 napban, akinek láza vagy légzési problémái voltak? (7) Részt vett-e bármilyen öszszejövetelen, vagy járt-e olyan helyen az elmúlt 14 napban, ahol sok emberrel került közeli kontaktusba? Ha a páciens bármelyik kérdésre igennel válaszol, de testhőmérséklete nem magasabb, mint $37,3{ }^{\circ} \mathrm{C}$, a kezelés 14 nappal halasztandó, a fogászati kezelés elvégzése nem javasolt. Ha bármelyik kérdésre igennel válaszol, és testhőmérséklete magasabb, mint $37,3^{\circ} \mathrm{C}$, a páciens azonnal elkülönítendő egy erre a célra előre kijelölt helyiségbe egyedül, és az illetékes helyi ellátóhelyet, illetve hatóságot haladéktalanul értesíteni kell. Ha minden kérdésre nemleges a válasz, és a beteg testhője alacsonyabb a korábban megadott küszöbértéknél, a kezelés megkezdhető a fent leírt infekciókontroll szabályainak szigorú betartásával. Ha minden kérdésre nemleges a válasz, és a beteg testhője magasabb $37,3^{\circ} \mathrm{C}$-nál, akkor a további ellátás céljából a beteget a háziorvosához kell irányítani $[42]$. 


\section{A jogszabályi háttér és az elvégezhetō, elvégzendö beavatkozások}

Magyarországon 2020. március 17. óta a fogászati ellátásra az országos tisztifóorvos 15150-1/2020/EÜIG rendelete van érvényben, mely szerint a hivatkozott rendelet visszavonásáig a fogászati szakellátást nyújtó egészségügyi szolgáltatók számára a nem sürgôs fogászati beavatkozások elvégzése tilos [42]. Az alapellátásban a 10/2020. (III. 14.) EMMI rendelet 2 . $\$$-a alapján szintén kizárólag sürgősségi ellátás nyújtására kerülhet sor [43]. A sürgősségi ellátás körében nyújtható beavatkozásokat a jogszabályi háttér (a 48/1997. [XII. 17.] NM rendelet 2 . sz. melléklete) tartalmazza [44].

\section{A fej-nyak terïletén dolgozó egyéb szakmákra vonatkozó rendelkezések}

Az EMMI 2020. március 21-i keltezéssel adta ki az Egészségügyi Szakmai Kollégium valamennyi tagozatának és tanácsának COVID-19-eljárásrenddel kapcsolatos szakmai ajánlását. Ezek közül a fogászattal és a szájsebészettel kapcsolatos kérdésekkel az előzőekben foglalkoztunk. A továbbiakban a fej-nyak régióját ellátó egyéb szakmákra vonatkozó megállapításokat foglaljuk össze [45].

A Fül-, Orr-, Gégészeti Szakmai Kollégiumi Tagozat deklarálja, hogy a szakma kezelőorvosai, asszisztensei fokozottan veszélyeztetettek, kitettségük miatt fokozott fizikokémiai barrierek alkalmazására van szükség az ellátás során. Külön szabályozzák a járó- és fekvőbeteg-ellátást. A betegváróban minimalizálni kell a betegszámot, a vizsgálatok előtt előszűrést kell végezni a sürgősség, illetve a COVID-érintettség tisztázására. A járóbeteg-ellátás során csak akut életveszélyes, illetve sürgős esetek láthatók el, minden egyéb esetben telefonos konzultációt javasolnak. Törekedni kell a kevesebb és rövidebb (maximum 15 perces) orvos-beteg találkozóra. Az ajánlás a kötelezően ellátandó sürgős esetek osztályozását (COVID+, COVID-) és megfelelő járványügyi biztonsági szintû védelemben való részesítését is részletezi. A fekvőosztályos ellátás kizárólag az akut, életveszély elhárítására és sürgősségi beavatkozások elvégzésére korlátozódik. Ezen mútétek esetén is törekedni kell a minél rövidebb hospitalizációra, lehetőség szerint az egynapos ellátásra. A fekvőosztályon szigorú látogatási tilalom betartatása javasolt. Az ajánlás a COVID+ eseteiben bejelentési kötelezettséget ír elő.

Az Idegsebészeti Szakmai Kollégiumi Tagozat az általános járványügyi szabályok betartatásán túl javaslatot tesz a betegforgalom, az orvos-beteg találkozások és az orvosi munkaidő csökkentésére. Az utóbbi esetben a részmunkaidő és a „home-office” bevezetését ajánlja. Mütét csak sürgősségi javallattal végezhető. A COVID+ eseteiben a betegellátás kizárólag a vészhelyzet elhárítására és a közvetlen életmentésre korlátozódik.

A Szemészeti Szakmai Kollégiumi Tagozat a betegellátás során egykapus betegutat, kérdőíves előszürést, szel- lős várókat, illetve fokozott kemomechanikai tisztítást javasol. COVID+ gyanúja esetén a szakvizsgálat halasztását rendeli el. A járóbeteg-szakrendelések közül csak az 5000 fö/évnél nagyobb forgalmú rendelések fenntartását tartja szükségesnek. A járóbeteg-ellátásban az előszűrés-osztályozás során 3 kategóriát állít fel (azonnali - mérlegelendő - halasztható/halasztandó esetek). A vizsgálati idő ne haladja meg a 15 percet. COVID(negatív) esetekben az orvosnak és az asszisztensnek sebészi maszk viselése ajánlott, a COVID+ eseteiben az orvosnak és az asszisztensnek teljes védőruházat, a betegnek szájmaszk és kézmosás javasolt, valamint az eset szakhatósági bejelentése kötelező. A fekvőosztályos ellátás a részletesen definiált sürgősségi kórképek mütéti kezelésére szorítkozik, ugyanakkor az ajánlás területi megkötést is tartalmaz, a megyei kórházak szemészeti osztályaihoz, illetve a III. progresszivitási szintú ellátóhelyekhez rendelve azt.

\section{Következtetések}

Látva a nemzetközi trendeket, egyértelmü, hogy a fejnyak területét érintő ellátás során a legszigorúbb elővigyázatossággal kell eljárni. Egyrészt mindenképpen elő kell szürni az épületbe belépő pácienseket, lehetőleg még a szabad levegőn, alap-védőfelszerelésben, lázat mérve és teljeskörüen kikérdezve a pácienst a lehetséges fertőzés tüneteiről. Másrészt az elengedhetetlenül szükséges kezelések elvégzését teljes védőfelszerelésben, tetőtől talpig beöltözve kell végezni, ügyelve a környezet folyamatos fertőtlenítésére is (minimum napi háromszor 30 perces fertőtlenítő takarítás). A külső védőruházat a keresztfertőzések megelőzése érdekében minden páciens után cserélendő. Az aeroszolképződés minimalizálása mellett fontos, hogy az ellátóteam tagjai megfelelő oktatásban részesüljenek a szükséges elővigyázatosságról és a védőfelszerelések használatáról. A fertőzés szempontjából különösen veszélyeztetett dolgozók egészségének védelme érdekében munkaszervezési intézkedések meghozatalára is szükség van. A jelen járvány olyan egészségügyi ellátási hozzáállást kíván, mellyel a jelenleg praktizáló szakemberek a munkájuk során még nem találkoztak, így az nagy kihívást jelent számukra. Ugyanakkor az egészségügyi ellátórendszerben a sürgósségi ellátások folyamatos rendelkezésre állását továbbra is biztosítani kell.

Anyagi támogatás: A munka anyagi támogatásban nem részesült.

Szerzői munkamegosztás: Az irodalmi összefoglalás elkészítése és a cikk megírása: Sz. R. M., A. M., V. T. A szakmai tartalom ellenőrzése, a cikk formázása: J. Z., P. J. A cikk végleges változatát valamennyi szerző elolvasta és jóváhagyta.

Érdekeltségek: A szerzőknek nincsenek érdekeltségeik. 


\section{Irodalom}

[1] National Center of Public Health. Guideline related to novel coronavirus identified in 2020 - March 16, 2020. [Eljárásrend a 2020. évben azonosított új koronavírussal kapcsolatban. Nemzeti Négészségügyi Központ, Budapest, 2020. 03. 16.] Available from: https://www.nnk.gov.hu/index.php/lakossagi-tajekoztatok/koronavirus/567-eljarasrend-a-2020-evben-azonositott-ujkoronavirussal-kapcsolatban-2020-03-16 [accessed: March 26, 2020]. [Hungarian]

[2] Bogoch A, Watts A, Thomas-Bachli C, et al. Pneumonia of unknown etiology in Wuhan, China: potential for international spread via commercial air travel. J Trav Med. 2020; 27: taaa008. Doi: $10.1093 / \mathrm{jtm} / \mathrm{taaa} 008$.

[3] Rothan HA, Byrareddy SN. The epidemiology and pathogenesis of coronavirus disease (COVID-19) outbreak. J Autoimmun. 2020 Feb 26. Doi: 10.1016/j.jaut.2020.102433. [Epub ahead of print]

[4] Paules CI, Marston HD, Fauci AS. Coronavirus infections. More than just the common cold. JAMA 2020; 323: 707-708.

[5] Chan JF, Yuan S, Kok KH, et al. A familial cluster of pneumonia associated with the 2019 novel coronavirus indicating person-toperson transmission: a study of a family cluster. Lancet 2020; 395: 514-523.

[6] Bai Y, Yao L, Wei T, et al. Presumed asymptomatic carrier transmission of COVID-19. JAMA 2020 Feb 21. Doi: 10.1001/ jama.2020.2565. [Epub ahead of print]

[7] Li Q, Guan X, Wu P, et al. Early transmission dynamics in Wuhan, China, of novel coronavirus-infected pneumonia. N Engl J Med. 2020; 382:1199-1207.

[8] Meng L, Hua F, Bian Z. Coronavirus Disease 2019 (COVID-19): emerging and future challenges for dental and oral medicine. J Dent Res. 2020 Mar 12. Doi: 10.1177/0022034520914246. [Epub ahead of print]

[9] Zhu N, Zhang D, Wang W, et al. A novel coronavirus from patients with pneumonia in China, 2019. N Engl J Med. 2020; 382: 727-733.

[10] Gorbalenya AE, Baker SC, Baric RS, et al. Severe acute respiratory syndrome-related coronavirus. The species and its viruses, a statement of the Coronavirus Study Group. bioRxiv 2020 Feb 11. Doi: https://doi.org/10.1101/2020.02.07.937862. [Epub ahead of print]

[11] Zhou P, Yang XL, Wang XG, et al. A pneumonia outbreak associated with a new coronavirus of probable bat origin. Nature 2020; 579: 270-273.

[12] Wax RS, Christian MD. Practical recommendations for critical care and anesthesiology teams caring for novel coronavirus (2019-nCoV) patients. Can J Anaesth. 2020 Feb 12. Doi: 10.1007/s12630-020-01591-x. [Epub ahead of print]

[13] Lu H, Stratton CW, Tang YW. Outbreak of pneumonia of unknown etiology in Wuhan, China: the mystery and the miracle. J Med Virol. 2020; 92: 401-402.

[14] Lake MA. What we know so far: COVID-19 current clinical knowledge and research. Clin Med (Lond). 2020; 20: 124-127.

[15] Phan LT, Nguyen TV, Luong QC, et al. Importation and human-to-human transmission of a novel coronavirus in Vietnam. N Engl J Med. 2020; 382: 872-874.

[16] Zhou P, Yang XL, Wang XG, et al. Discovery of a novel coronavirus associated with the recent pneumonia outbreak in humans and its potential bat origin. bioRxiv 2020 Mar 13. Doi: https:// doi.org/10.1101/2020.01.22.914952. [Epub ahead of print]

[17] Holshue ML, DeBolt C, Lindquist S, et al. First case of 2019 novel coronavirus in the United States. N Engl J Med. 2020; 382: 929-936.

[18] Xia J, Tong J, Liu M, et al. Evaluation of coronavirus in tears and conjunctival secretions of patients with SARS-CoV-2 infection. J Med Virol. 2020 Feb 26. Doi: 10.1002/jmv.25725. [Epub ahead of print]
[19] Government of Canada. Infection prevention and control for novel coronavirus $(2019-\mathrm{nCoV})$ : interim guidance for acute healthcare settings. html $2020 \mathrm{Feb} 24$. https://www.canada.ca/ en/public-health/services/diseases/2019-novel-coronavirusinfection/health-professionals/interim-guidance-acute-healthcare-settings [accessed: March 21, 2020].

[20] van Doremalen N, Bushmaker T, Morris DH, et al. Aerosol and surface stability of SARS-CoV-2 as compared with SARS-CoV-1. N Engl J Med. 2020 Mar 17. Doi: 10.1056/NEJMc2004973. [Epub ahead of print]

[21] Backer JA, Klinkenberg D, Wallinga J. Incubation period of 2019 novel coronavirus (2019-nCoV) infections among travellers from Wuhan, China, 20-28 Jan 2020. Euro Surveill. 2020; 25: pii=2000062. Doi:10.2807/1560-7917.

[22] Huang C, Wang Y, Li X, et al. Clinical features of patients infected with 2019 novel coronavirus in Wuhan, China. Lancet 2020; 395: 497-506.

[23] Chen N, Zhou M, Dong X, et al. Epidemiological and clinical characteristics of 99 cases of 2019 novel coronavirus pneumonia in Wuhan, China: a descriptive study. Lancet 2020; 395: 507513.

[24] Wang D, Hu B, Hu C, et al. Clinical characteristics of 138 hospitalized patients with 2019 novel coronavirus-infected pneumonia in Wuhan, China. Published online ahead of print, $2020 \mathrm{Feb}$ 7. JAMA 2020; 323: 1061-1069.

[25] Hopkins C, Kumar N. Loss of sense of smell as marker of COVID-19 infection. Available from: https://www.entuk.org/ sites/default/files/files /Loss $\% 20$ of $\% 20$ sense $\% 20$ of $\% 20$ smell\%20as\%20marker\%20of\%20COVID.pdf [accessed: March $25,2020]$.

[26] Novel Coronavirus Pneumonia Emergency Response Epidemiology Team. The epidemiological characteristics of an outbreak of 2019 novel coronavirus diseases (COVID-19) in China. Zhonghua Liu Xing Bing Xue Za Zhi 2020; 41: 145-151. [Chinese]

[27] Wei J, Li Y. Airborne spread of infectious agents in the indoor environment. Am J Infect Control 2016; 44(9 Suppl): S102S108.

[28] Cleveland JL, Gray SK, Harte JA, et al. Transmission of bloodborne pathogens in US dental health care settings: 2016 update. J Am Dent Assoc. 2016; 147: 729-738.

[29] Patel ZM, Fernandez-Miranda J, Hwang P, et al. HNO-CoronaNews-Ticker. Available from: https://cdn.hno.org/media/Corona-Ticker/Information_Univ_Stanford_-_Endoscopic_Surgery.pdf [accessed: March 25, 2020].

[30] Meco C, Plzak J, Tedla M, on behalf Confederation of the European Otorhinolaryngology and Head and Neck Surgery Presidential Council. CEORL-HNS statement to COVID-19. Available from: https://www.ceorlhns.org/covid-19 [accessed: March 25, 2020].

[31] American Association of Oral and Maxillofacial Surgeons. COVID-19 guidance for OMS practices. AAOMS, Rosemont, IL. Available from: https://www.aaoms.org/news/covid19-updates\#1 [accessed: March 26, 2020].

[32] American Academy of Otolaryngology-Head and Neck Surgery. AAO-HNS position statement: otolaryngologists and the COVID-19 pandemic. AAO-HNS, Alexandria, VA. Available from: https://www.entnet.org/content/aao-hns-positionstatement-otolaryngologists-and-covid-19-pandemic [accessed: March 25, 2020].

[33] Samaranayake LP, Reid J, Evans D. The efficacy of rubber dam isolation in reducing atmospheric bacterial contamination. ASDC J Dent Child. 1989; 56: 442-444.

[34] Samaranayake LP, Peiris M. Severe acute respiratory syndrome and dentistry: a retrospective view. J Am Dent Assoc. 2004; 135: 1292-1302.

[35] Lai G, Capi CL, Cocco F, et al. Comparison of Carisolv system vs traditional rotating instruments for caries removal in the pri- 
mary dentition: A systematic review and meta-analysis. Acta Odontol Scand. 2015; 73: 569-580.

[36] Li R, Zhao Y, Ye L. How to make choice of the carious removal methods, Carisolv or traditional drilling? A meta-analysis. J Oral Rehabil. 2014; 41: 432-442.

[37] Frencken JE. Atraumatic restorative treatment and minimal intervention dentistry. Br Dent J. 2017; 223: 183-189.

[38] Peng X, Xu X, Li Y, et al. Transmission routes of 2019-nCoV and controls in dental practice. Int J Oral Sci. 2020; 12: 9.

[39] Kampf G, Todt D, Pfaender S, et al. Persistence of coronaviruses on inanimate surfaces and their inactivation with biocidal agents. J Hosp Infect. 2020; 104: 246-251.

[40] T. Liang, Zhejiang University, School of Medicine. Handbook of COVID-19 prevention and treatment. 2020 March 24. Available from: https://iau-aiu.net/Zhejiang-University-Handbookof-COVID-19-Prevention-and-Treatment [accessed: March 25, 2020].

[41] European Center for Disease Prevention and Control. ECDC Technical report. Guidance for wearing and removing personal protective equipment in healthcare settings for the care of patients with suspected or confirmed COVID-19. ECDC, Solna, 2020 February. Available from: https://www.ecdc.europa.eu/ sites/default/files/documents/COVID-19-guidance-wearingand-removing-personal-protective-equipment-healthcare-settings-updated.pdf [accessed: March 25, 2020].

[42] National Center of Public Health. Departmental order by the head physician in Hungary. Budapest, 2020 March 17. [Országos tisztifőorvosi határozat, 15150-1/2020/EÜIG.] Nemzeti
Népegészségügyi Központ, Budapest, 2020. március 17. Available from: https://www.kamara.fogorvos.hu/?module=news\&a ction $=$ getfile\&fid=253749 [accessed: March 23, 2020]. [Hungarian]

[43] Ministry of Human Capacities. Decree No. 10/2020 (III. 14.). [10/2020. (III. 14.) EMMI rendelet.] Emberi Erőforrások Minisztériuma, Budapest, 2020. március 14. Available from: http://semmelweis.hu/fok-tovabbkepzes/files/2020/03/ 10_2020-iii_14-emmi-rendelet.pdf [accessed: March 23, 2020]. [Hungarian]

[44] Ministry of Public Welfare. Decree No. 48/1997 (XII. 17.). [48/1997. (XII. 17.) NM rendelet.] Available from: https:// net.jogtar.hu /getpdf?docid $=99700048$. nm\&targetdate $=20080$ $516 \&$ print Title $=48 / 1997 .+\% 28$ XII $+17 . \% 29+\mathrm{NM}+$ rendelet [accessed: March 23, 2020]. [Hungarian]

[45] Recommendation of the Hungarian Ministry of Human Capacities, College of Health and Medicine, concerning the COVID-19 pandemy. [Emberi Erőforrások Minisztériuma, Egészségügyi Szakmai Kollégium ajánlása a COVID-19-ellátásrenddel kapcsolatban.] Available from: https://kollegium.aeek.hu/(X(1) S(idhhr2um4zw30sa0qif31r4e))/Dokumentumok/Index [accessed: March 25, 2020]. [Hungarian]

(Antal Márk dr., Szeged, Tisza Lajos krt. 60-64., 6720 e-mail: antalmarkdr@gmail.com)

A cikk a Creative Commons Attribution 4.0 International License (https://creativecommons.org/licenses/by/4.0/) feltételei szerint publikált Open Access közlemény, melynek szellemében a cikk bármilyen médiumban szabadon felhasználható, megosztható és újraközölhetö, feltéve, hogy az eredeti szerző és a közlés helye, illetve a CC License linkje és az esetlegesen végrehajtott módosítások feltüntetésre kerülnek. (SID_1) 